\title{
PROMOTING ISLAM NUSANTARA: A Lesson from Nahdlatul Ulama (NU)
}

\section{Abstract:}

NU has explicitly voiced the importance of the Muslims within and outside the country to reconsider and rethink the concept of Islam Nusantara. It is such a historical consciousness could be seen clearly from the roles played by the religious social organization in materializing the teachings of Ahlussunnah wal jamaah (Aswaja). In this capacity, NU has been capable of brilliantly articulated religious teachings that are at least based on three aspects, namely the normative doctrinal, historical and cultural. The success of $N U$ in propagating the the concept of Islam Nusantara is due to the role of its prominent clerics and Muslim scholars (ulema) for skilfully being able to sow the seeds of Islamic teachings in a peaceful and courteous means in the face of different cultures, traditions and customs inherited and developed by the so-called Walisongo. On this stand, NU is committed to doing its best services for the country and even taking part in internationalizing its moderate and tolerant teachings of Islam to other countries.

Keywords: Islam Nusantara, historical consciousness, cultures

Sudarto Murtaufiq

Lecturer at Islamic University of Lamongan (UNISLA) and senior editor of NU Online, the official news portal of the Central Board of Nahdlatul 


\section{A. Introduction}

The discourse of so-called Islam Nusantara or "Islam of the Archipelago" has been widely discussed, especially when the term became an interesting theme in the NU 33rd Conference in Jombang, East Java, on August 1 - 5, 2015. The theme seems to be a big leap for the Indonesia's largest Muslim organization in materializing the values of Islam Nusantara that are normatively in line with the doctrinal teachings of so-called Islam Ahlussunnah wal jamaah (Aswaja).

According to Azyumardi Azra the term "Islam Nusantara" in the academic world refers to "Southeast Asian Islam" consisting of such Muslim countries as Indonesia, Malaysia, Brunei, Pattani (Southern Thailand) and Mindanao (southern Philippines). In the pre-colonial literatures it was called the "lands below the wind. More specifically in the Arabic literature since the 16th century, the Islam Nusantara region is called "Bilad al-Jawi", namely Southeast Asia. The Muslims of Nusantara commonly are referred to as " ashab al-Jawiyyin" or "jama'ah al-Jawiyyin". ${ }^{1}$

Islam Nusantara region is one of the eight religio-cultural domains of Islam. Seven others are Arabic, Persian / Iranian, Turkish, Indian subcontinent, Sino Islamic, Black Africa and the Western World. Despite holding the same key principles and teachings in the creed and worship, but each domain has its own religious character and cultures. ${ }^{2}$

Meanwhile, according to Akhmad Sahal, the understanding about Islam Nusantara entails interlocking relationship between religious and cultural dimensions. These dimensions make Islam capable of interacting with territorial limits which have particular cultural roots. Thus, Islam no longer displays a gloomy, rigid and closed face, but it respects for any possible differences, let others present in social and cultural spaces. On this stand, Islam is very accommodating social values and cultures having long been standing for centuries. This is stated also by Abdurrahman Wahid (Gus Dur), that "The overlap between religion

\footnotetext{
${ }^{1}$ Azyumardi Azra, "Islam Indonesia Berkelanjutan", in Opini Kompas, 3 August 2015.

${ }^{2}$ Ibid.
} 
and culture will occur continuously as a process that will enrich life and make it live in harmony." 3

Undeniably, the term Islam Nusantara will continue to be a discourse and open up spaces for debate. KH. Mustafa Bisri (Gus Mus), the NU prominent figure, for example, once described the term. According to him, the term Nusantara (archipelago) should be understood in the idhafah construction instead of being understood in the so-called na'atman'ut one. As a result it means "Islam in (or of) the archipelago ".4

Meanwhile, Teuku Kemal Fasya in his essay, Poetic and Cultural Dimensions of Islam Nusantara defines that Islam Nusantara is the process of appreciating and practicing the locality of the people living in the archipelago. The word "Nusantara" is not simply affirming the name of place or noun, but more importantly, it is such an adjective explanation in addition to depicting the quality of Islam "here/Nusantara" in contrast to the one "over there". The success of Islam to be a peaceful archipelagic religion is inseperable from such factors as adaptability and knowledge, local wisdom and culture. Theological creeds could address the cultural dimension and resonate through local knowledge. ${ }^{5}$

Regardless of the various terms related to Islam Nusantara leading to a number of terminological consequences, Islam Nusantara culturally littered fully with value systems has still influenced the development of Islam in Indonesia today. For centuries, the seeds of Islam Nusantara have already been sown in the country and provided a functional tool that gives religious color to the life of the nation as a whole.

Thus, the ideas of Islam Nusantara as a blueprint for being 'institutionalized' in various belief systems or religious traditions both maintained and preserved by especially Nahdlatul Ulama (NU) have been inseparable from the process of dakwa (religious propaganda) or the spread of Islam in Indonesia for centuries. On this stand, NU has

\footnotetext{
${ }^{3}$ Akhmad Sahal (eds.), Islam Nusantara Dari Ushul Fiqh hingga Paham Kebangsaan, (Bandung: Mizan Pustaka, 2015), p. 33.

${ }^{4}$ Edi AH Iyubenu, "Ontran-Ontran Islam Nusantara", in Opini Jawa Pos, 24 July 2015.

5 Teuku Kemal Fasya, "Dimensi Puitis dan Kultural Islam Nusantara", in Opini Kompas, 4 August 2015.
} 
successfully worked to 'Islamize' the values of Nusantara at least through three doctrines of orthodoxy. Firstly, in the field of theology, NU embraces the ideology of al-Asy'ari and al-Maturidi. Secondly, in the field of Islamic jurisprudence, NU follows the four schools of thought (madzhab), namely Hanafi, Maliki, Syafi'i and Hanbali. Thirdly in the field of sufism (tasawuf), NU embraces the thought of Imam Junaid alBaghdadi and Imam al-Ghazali. Through these three doctrines of orthodoxy, NU has managed to bring an Islamic face-Islam Nusantarathat is different from the one in various parts of the world.

Islam Nusantara nationally and internationally propagated by NU is a typical Indonesian Islam that promotes tolerance in addition to accepting differences, whether religious, ethnic, racial, or cultural. Thus, the NU doctrine of Islam Nusantara becomes a stepping stone in building solidarity through such inclusive values as tawasuth (moderation), tasamuh (tolerance), taáwun (mutual help), tawazun (harmony), and others. On this stand, the roots of the inclusive values have plunged on the basis of the awareness of Muslims in Indonesia. Instead of expressions of worship and religious rites alone, Indonesian Islam has also been formed by and embedded in it the aspects such as cultures, traditions, customs and others.

The religious life of Muslims at this time could not be separated from the process of dakwa (religious propaganda) or the spread of Islam in Indonesia since a few centuries earlier. Before Islam arrived in Indonesia, the archipelago cultures had mostly been influenced by longstanding religions such as Hinduism and Buddhism, including various traditional beliefs such as animism, dynamism, and so on. The Islamic cultures eventually became small traditions in the swirl of the great traditions of Hinduism and Buddhism. The small traditions then affected each other and maintained their existence. ${ }^{6}--$

\footnotetext{
${ }^{6}$ George W. Braswell, Islam: Its Prophet, Peoples, Politics and Power (Nashville: Broadman \& Holman Publishers, 1996). See also Arbiyah Lubis, Pemikiran Muhammadiyah dan Muhammad Abduh, Suatu studi Perbandingan (Jakarta: Bulan Bintang, 1993); Hamid Algadari, Dutch Policy Against Islam and Indonesian of Arab Descent in Indonesia (Jakarta: LP3ES, 1994), p. 21; Arohman Prayitno, Trubus Rahardiansyah P., Ethics
} 
The regions in the archipelago firstly becoming a snapshot of the spread of Islam are trading centers in urban communities in coastal areas. While orthodox Islam could enter deeply in regions outside Java, which are not much influenced by the values and traditions of both Hinduism or Buddhism. Unlike in Java. In this region, Islam faced resistance from Hinduism and Buddhism having long been established. At this point, Islam did not just have to tame its target but also had to tame itself. In the face of local conflict and cultural resistance, Islam must be able to get the symbols aligned with the local cultures. ${ }^{7}$

The ability of Islam to adapt to local cultures has paved the way for reaching the grassroots. As a result, Islamic cultures are strongly influenced by the farmers and inland ones, so that the Islamic cultures could undergo a transformation not only because of the geographical distance between the Arab and Indonesia, but also because of cultural distances. ${ }^{8}$

On this stand, the process of cultural compromise would bring possible risks because in certain circumstances it is often tolerant of interpretation which might be considered to deviate from the pure Islamic teachings. The cultural compromise could eventually give birth what is on the island of Java known as syncretism or Islam Abangan. While on the island of Lombok it is known as Islam Wetu Telu. ${ }^{9}$

The Islamization process that took place in the archipelago is inseparable from the process of acculturation. As already known that the spread of Islam in the archipelago is a normative aspect in addition art and cultural one. Meanwhile, society and culture in which Islam was disseminated are an empirical nature. In this context, as intelligent

for a Multicultural Society: Strategic Solutions for Interweaving Togetherness the Frame Work of Pluralism (Jakarta: Trisakti University Press, 2008), p. 67.

${ }^{7}$ Taufik Abdullah, "Pengantar: Islam, Sejarah dan Masyarakat", in Taufik Abdullah [ed.], Sejarah dan Masyarakat: Lintasan Historis Islam di Indoensia (Jakarta: Pustaka Firdaus, 1987), p. 3

${ }^{8}$ Hildred Geertz, "Indonesian Cultures and Communities," in Indonesia, ed. Ruth T. McVey (New Haven, CT: Human Relations Area Files, 1963), p. 6.

${ }^{9}$ Muhammad Harfin Zuhdi, Parokialitas Adat terhadap Pola Keberagamaan Komunitas Islam Wetu Telu di Bayan Lombok (Jakarta: Lemlit UIN Jakarta, 2009), p. 111. 
beings, humans are basically religious and consequently will know best their own world. In a consequence, through their cultural behavior, humans will constantly improve their self-actualization. Therefore, in each acculturation, humans create, utilize, change things in accordance with their needs.

From this paradigm, within the framework of acculturation, there emerges what is known as a local genius. On this stand, the local genius could be defined as the ability to absorb while conducting selection and actively dealing with the cultural influences, in order to achieve a new unique creation that is not contained in the nation that brings its cultural influence. ${ }^{10}$

On the other hand, implicitly the local genius could be specified its characteristics, namely: the ability of withstanding the outside world, accommodating outside elements; integrating foreign cultural elements into the original ones in addition to controlling and giving direction to the subsequent cultural development. ${ }^{11}$

\section{B. Retraditionalizing and Reideologizing Islam Nusantara}

Islam Nusantara that seems to be a historical consciousness could be seen clearly from the roles played by Nahdlatul Ulama (NU) as the largest organization in the country. In this capacity, NU has been capable of brilliantly articulated religious teachings that are at least based on three aspects, namely the normative doctrinal, historical and cultural. Therefore, the NU Muslim scholars (ulema) are skilfully able to sow the seeds of Islamic teachings of Ahlussunnah wal Jamaah in a peaceful and courteous means in the face of different cultures, traditions and customs inherited from the pattern of dakwa as developed by the so-called Walisongo. In this context, there should be processes of retraditionalizing and reideologizing Islam Nusantara in its very cultural form, especially when a set of values are arranged to form a complete and intact ideology. Islamic values having long animated the lives of Muslims in Indonesia, for example are attempted to be revived

\footnotetext{
${ }^{10}$ Harry Parkin, Batak Fruit of Hindu Thought (India: Christian Literature Society, 1978), p. 28.

${ }^{11}$ Soerjanto Poespowardojo, "Pengertian Local Genius dan Relevansinya dalam Modernisasi" dalam Kepribadian Budaya Bangsa (local genius), ed. Ayotrohaedi (Jakarta: Pustaka Jaya, 1986), p. 28-38.
} 


\section{Promoting Islam Nusantara}

unanimously and completely. In turn, the ideological framework is a must. However, the ideology is necessarily not meant a political ideology, but a cultural one, like calls to create-as said by Abdurrahman Wahid-complete Islamic societies in which the values of Islam could fully be developed without any distortion. ${ }^{12}$ Thus, the process will result in efforts to retraditionalize the Islam Nusantara. That is, when the traditions in the past are inherently tied to each other with the intact framework of traditions, namely between tradition and ideology, although only a cultural ideology. In turn, there will expectedly be a relation to support and strengthen each other.

The face of religiosity in Indonesia has met its maturity because it could change its face to become the Nusantara (archipelago). Islam Nusantara is a form of maturity reflected from the universal teachings of Islam. Empirically, it is able to survive in the many non-Arab cultures. It has till now helped create cultural spaces inhabited by non-Muslims though. ${ }^{13}$

In this context, culture is humane in nature. That is the manifestation and the realization of all human activities in an effort to simplify and address their need. Culture consists of values and symbols. Cultural values are invisible, while the cultural symbols that represent the values could clearly be seen or identified. Various forms of cultural symbols, such as mosques, markets, schools, homes for example, are the embodiment of the cultural values of their society. In any human activity, cultural values are always present and are inherent with the value systems although sometimes it is not necessarily a symbol of culture. ${ }^{14}$

In this context, man is able to find out through a pattern of sowing the seeds of noble values of Islam Nusantara, at least with dakwa (propagation) in all its forms. Dakwa is none other than a call for humanity to the path of God, which is the path to Islam. Islam derived

\footnotetext{
${ }^{12}$ See Abdurrahman Wahid, Islam Kosmopolitan: Nilai-Nilai Indonesia dan Transformasi Kebudayaan (Jakarta: The Wahid Institute, 2007), p. 193.

${ }^{13}$ A. Musthofa Haroen, Meneguhkan Islam Nusantara: Biografi Pemikiran dan Kebangsaan Prof. Dr, KH. Said Aqil Siroj, MA (Jakarta: Khalista, 2015), p. 121.

${ }^{14}$ F Allan Hanson, Meaning in Culture (London and New York: Routledge, 2004), 99-100.
} 
from the revelation of God and the Sunnah of His Messenger, is the source of value that will provide the style, color and form of Islamic culture. A form of culture which contains a message or Islamic values, may appear on individuals or people outside Islam. Vice versa, it does not say Islamic culture, even though it was born of one or society that adheres to the teachings of Islam, if it does not contain the Islamic messages or values. As a theological actualization, the Islamic dakwa is actualized in various systems of social activities to at least affect people in realizing the teachings of Islam in all aspects of life by using a certain way.

In this perspective, culture is the actualization of human submission to God. As stated in Qur'an which means: "And the poets - [only] the deviators follow them; Do you not see that in every valley they roam; And that they say what they do not do? Except those [poets] who believe and do righteous deeds and remember Allah often and defend [the Muslims] after they were wronged. And those who have wronged are going to know to what [kind of] return they will be returned."15

The above verse implies that there are two types of culture represented by the pious cultural actors. Firstly, the culture that is built through the dimensions of taqwa, represented by the pious cultural actors who always remember their God and is in patience in the face of injustice. If it is agreed that culture is specifically humane, the influence of ideology, world view, attitudes and ways of thinking of the cultural actors become the basis of the cultural forms. Thus, a person who has individual and social piety will certainly give birth to the kind of culture that paves the way for other people or society to become pious (khair alummah). Secondly, the culture built through the dimensions of heresy and ignorance. Those having communist background or capitalist ideology, for example, will also display the form of cultural orientations and ways of thinking the ideology referred to in order to build their community.

Furthermore, the relationship between Islam as a religion and the local culture is very clear in the study of anthropology of religion. In this

${ }^{15}$ (Q.S.Asy-Syua'ara [26]: 224-227). 
perspective it is believed that religion is the embodiment of a cultural system. ${ }^{16}$ On this stand, Islam as a divine religion is considered an incarnation of the cultural system of a Muslim society. The thesis is then developed in the aspects of Islamic teachings, including the legal ones. Both anthropologists and sociologists approach the Islamic law as a Muslim cultural institution. In the present context, the legal studies through sociological and anthropological approaches have been developed by Muslim jurists who care about the fate of the Shari'a. In their view, if the shari'a is only approached doctrinally (and not sociohistorically), there will likely be the standardization of the norms of sharia, which in essence are dynamic and accommodate changes in society. ${ }^{17}$

Islam as a religion, culture and civilization of the world has come into Indonesia in the 7th century and continued to grow until now. It has contributed to the cultural diversity of the archipelago. Islam is not only present in the great tradition but has also enriched the cultural plurality through the Islamization and indigenization of Islam, which in turn gave birth to the many little traditions of Islam. Various colors of Islam-Aceh, Malay, Java, Sunda, Sasak, Bugis, and others-have given certain patterns of diversity, which consequently may be ambiguous. The ambiguity or ambivalence is a religious function that is generally accepted from the sociological point of view. ${ }^{18}$

Speaking of the influence of local culture and customs in relation to religion, no doubt there is an attempt to articulate the message of religiosity with local content. The religious encounter with the local culture could take many forms. Firstly, there will be a clash in which the local culture is wiped out and replaced with new ones through the process

\footnotetext{
${ }^{16}$ Bassas Tibbi, Islam and Cultutral Accommodation of Social Change (San Francisco: Westview Pres, 1991), p. 1. See also Mary-Paula Walsh, Feminism and Christian Tradition: An Annotated Bibliography and Critical Introduction to the Literature (London, Greenwood Press, 1999)

${ }^{17}$ Muhammad Harfin Zuhdi, "Dakwah dan Dialektika Akulturasi Budaya”, in Religia, jurnal Ilmu-Ilmu Keislaman, Vol. 15, No. 1, April, 2012.

${ }^{18}$ John Bresnan, Indonesia: The Great Tradition (Maryland, Roman and Littlefield Publishers, Inc., 2005), p. 83
} 
of Islamization as happened in Padang in the past. Secondly, it could be carried out through the way of accommodation. That means there is complementary dialogue between one another. In this context, Islam is merely accepted through its symbolic content. While, its substance such as beliefs in ancestors is still preserved. Thirdly, it could be through the way of hybridity by accepting the religion but only half of it, and the rest is through local tradition. This form is then commonly known as, for example, Java Islam, Banjar Islam, Sasak Islam and so forth. Thus, efforts of reideologizing and retraditionalizing Islam Nusantara has a solid footing in the doctrinal, historical and cultural spaces. ${ }^{19}$

\section{The encounter of Islam (Nusantara) with Local Tradition}

The dakwa (propagation) carried out by the earlier propagators of Islam in the archipelago have shown a strong accommodation to the local tradition. So Islam came not as a threat, but was a friend playing an important role in the transformation of culture. This implies that the character of Indonesian Islam having a dialogue with the local tradition was actually carried by the Indian preachers in the early spread of Islam in Indonesia having accommodating relations with the local tradition or culture of local communities than Saudi puritan preachers in eradicating the practices of local communities. The character of Islam brought by the Indian people was continued by the Walisongo in preaching the Islamic teachings in Java. ${ }^{20}$

The dialogue process of Islam with local traditions is embodied in the cultural space in the face of local negotiations. Islam is not necessarily taken for granted in the encounter with the local treasuries. In this context, either Islam or community traditions have a balanced position to have a cultural negotiation creatively without making another marginalized, resulting in mutual weaken. The combination between Islam and the traditions, therefore, is the result of an encounter in the cultural space as well as a wealth of local interpretation thus making

\footnotetext{
${ }^{19}$ Ahmad Baso, Plesetan Lokalitas: Politik Pribumisasi Islam (Jakarta: Desantara, 2002), p. 3.

${ }^{20}$ Vincent J. Cornell (ed.), Voices of Islam, Vol. 5 (London: Praeger Publisher, 2007), p. 172. See also John Renard, Tales of God's Friends: Islamic Hagiography in Translation (California: University of California Press, 2009), p. 341.
} 
Islam could still 'greet' the true reality. Again, in this context, Islam must not be perceived as the one in Arabic, but must engage in dialogue with local traditions. ${ }^{21}$

Meanwhile, Agus Sunyoto explained that the mechanism of cultural processes in the body of Islamisation, Walisongo did it through education by establishing Shiva-Buddhist educational institutions that are in accordance with the teachings of Islam into Islamic boarding schools (pesantren). The effort could lead to stunning results for Sufi masters (Walisongo) were able to formulate the socio-cultural and religious values professed by the Shiva-Buddhist followers with the Islamic ones, especially the values of monotheism of Shiva-Buddhist (adwayasashtra) with the monotheistic teachings of Islam as adopted by the Walisongo. ${ }^{22}$

Meanwhile, Said Aqil Siroj, the General Chairman of NU, also said that in the age of Walisongo, pesantren having formerly been littered fully with the teachings of Hinduism and Buddhism could culturally be influenced with the teachings of Islam. On account of the presence of pesantren, religion was taught widely in society. All that was taught in depth by studying various primary books that gave birth to great ulema or scholars and contributed to the history of Islam Nusantara. Such individuals as Pakubowono VI, Prince Sambernyowo (Mangkunegoro I) and Prince Diponegoro are great characters who are well versed in politics and has never been beaten in the war. All this is due to the role of pesantren. ${ }^{23}$

Geographically anciently the places of pesantren were deliberately chosen far from the crowds, residential areas, the capital of the kingdom as well as big cities. The students were garrisoned and financed by the teachers concerned, or at the expense of fellow Muslims. The students learned in separate booths but most of the time was used to do such

\footnotetext{
${ }^{21}$ Khamami Zada, "Islam Pribumi: Mencari Wajah Islam Indonesia”, in Tashwirul Afkar, jurnal Refleksi Pemikiran Keagamaan \& Kebudayaan, Edisi No. 14, 2003.

${ }^{22}$ Agus Sunyoto, Walisongo: Rekonstruksi Sejarah yang Disingkirkan (Jakarta: Transpustaka, 2011), p. 94.

${ }^{23}$ Said Aqil Siroj, Islam Sumber Inspirasi Budaya Nusantara Menuju Masyarakat Mutamaddin (Jakarta Pusat: LTN NU, 2015), p. 4.
} 
activities as cleaning or planting. Some schools were built on a hill or slope. For example, Mount Muria in Central Java and Pesantren Giri that is located on top of a hill called Giri near Gresik in East Java.

Furthermore, the history of pesantren in Indonesia is closely linked with the history of Islam itself. As a fact that the historical facets of pesantren in the archipelago are in line with the historical evidence of the socialization of Islam. ${ }^{24}$ Moreover, the historical evidence also shows that pesantren have always chosen a neutral position. Since the 16th century there has been a strong presumption that pesantren are such a dynamic factor in every process of the history and struggle of the nation. Harry J. Benda-as quoted by Hasan Muarif Ambary-even came to a conclusion that the history of Indonesian Islam is the one of expanding the civilization of santri (students) and their influence on the fields such as religious, social and political in Indonesia. Islam has brought a new civilization, a system that is accessible to all levels of society. The system is built and based on an operational consequence of the concept of "ummah" in Islam that is egalitarian and put in common human dignity before God. ${ }^{25}$

In addition, the model of teaching in pesantren is run massively and individually. It is run massive for being focused more on general subject matters and is run individually for being focused on those willing to deepen their knowledge. While the system of madrasa (Islamic education) with formal curriculum began to be applied around the 19th or early 20th century. Islamic educational institutions at that time were gradually run from the low, medium and high level. Thus, the existence of pesantren in Indonesia's history has come to a hypothesis that the pesantren in social change has always served as a platform for distributing and disseminating the teachings of Islam. ${ }^{26}$

\footnotetext{
${ }^{24}$ Agus Aris Munandar, "Kegiatan Keagamaan di Pawitra Gunung Suci di Jawa Timur Abad 14-15”, Tesis, Magister Humaniora Fakultas Sastra Universitas Indonesia, 1990, p. 311.

${ }^{25}$ Hasan Muarif Ambary, Menemukan Peradaban; Jejak Arkeologis dan Historis Islam Indonesia, Cet. II (Jakarta: Logos Wacana Ilmu, 2001), p. 318.

${ }^{26}$ Ibid.
} 
Inevitably, Islam as a religion spreading around the world could hold a creative dialogue with the local community in a position to accept its traditions in addition to modifying it into a new culture that could be accepted by the local community and still be on the path of Islam. Therefore, the arrival of Islam is an enlightenment for Southeast Asia, particularly Indonesia, because Islam stresses the importance of intellectualism that could not clearly be seen on Hinduism-Buddhism. In fact, the displacement of Indonesian society from the religious system and Hindu-Buddhist culture to Islam is equated with a change in the outlook of the Western World which was originally influenced by Greek mythology to the world of reason and enlightenment. A reconciliation of Islam with local tradition is believed to be the process of admission that is done naturally and peacefully without conquest. This is different from that in the Middle East, where Islam spread through a process of political power. $^{27}$

The dialogue of Islam with this tradition is carried out in the spirit of negotiation. It is a process of interpreting something present and interpret itself to look for a new something that is culturally known as a living thing. ${ }^{28}$ In a cultural context, people have the ability to negotiate with their own way. And in reality, the struggle between the attended (local community) and attending (Islam) parties in negotiations is not based on the spirit of changing each other, because when it changes each other, it is no longer called as a negotiation, but is a hegemony even repression. That means the negotiation is part of a cultural transformation within the cultural movement. The process that occurs is the creative one in a spirit of culture, so that both parties are located in the equal structure. ${ }^{29}$

In other words, negotiations are an attempt to eliminate or decrease the power of incoming tradition. It serves to harmonize foreign influences with local wisdom. Through the negotiation the novelty

\footnotetext{
${ }^{27}$ Azyumardi Azra dan Wayne Hudson (eds.), Islam beyond Conflict: Indonesian Islam and Western Political Theory (England: Ashgate Publishing Limited, 2008)

${ }^{28}$ Khamami Zada, "Islam Pribumi: Mencari Wajah Islam Indonesia”, dalam Tashwirul Afkar, jurnal Refleksi Pemikiran Keagamaan \& Kebudayaan, Edisi No. 14, 2003.

${ }^{29}$ Clifford Geerrtz, The Interpretation of Cultures (New York: Basic Books, 1973)
} 
outside the tradition is not taken for granted, but is modified from its authenticity, adapted to the power of welcoming the tradition. Efforts of negotiating with traditions is a natural thing. None of the traditions that does not have a negotiation, namely the ability to apply what belongs to the local (as origin) by adjoining or defining what is on the outside into a something (as part of a creative process). In the negotiation process there are attempts comparison with its own, there are pragmatic and probably ideological considerations and the intention to use it anew. In short, the negotiation suggests a creative interpretation of the "buyer" or user. ${ }^{30}$

Negotiations are also associated with efforts to eliminate the power of incoming traditions. The second definition is closely linked with the assumption that every local is inhabited by the powers of politics or truth. The arrival of incoming tradition more or less will disturb the local authority. Therefore, naturally the local traditions will use the incoming ones to articulate their interests, or use them as a new bargaining power to strengthen their position in front of the dominating and hegemonic power.

Negotiations between the religious and cultural values occur because there is a potential relevant to each other. The potential could maintain the encounter between religious and cultural values. ${ }^{31}$ Conversely, if in the two values there is not a potential relevant to each other, then all forms of antagonism in society with all its implications will emerge. Of course, with the assumption that every tradition in itself already has a set of values about what is suitable or not suitable for itself or what is necessary for the development and what is hindering its growth. Herein lies the meaning of the term resistance. It is used to measure what happens when two different traditions carry out the process of interpreting and adjusting to each other until eventually leading to an agreement in the pattern of communication or interaction used together.

\footnotetext{
${ }^{30}$ Muhammad Harfin Zuhdi, "Dakwah dan Dialektika Akulturasi Budaya”, in Religia, jurnal Ilmu-Ilmu Keislaman, Vol. 15, No. 1, April, 2012.

${ }^{31}$ Fachry Ali, Agama, Islam dan Pembangunan (Yogyakarta: PLP2M, 1985), p. 76.
} 
In the span of a long history, the negotiation process between Islam and local cultures or traditions occurs in a structure: dyeing and dyed. Namely, Islam will color the traditions or otherwise it is colored by traditions within the spirit of reconciliation. This reciprocal process brings a harmonious shade in the pattern of Islam Nusantara. A lot of evidence show how Islam Nusantara is capable of holding a dialogue with the local tradition creatively without weakening and destroying it. On this stand, Islam Nusantara has a good epistemological footing in terms of the historical, cultural and even doctrinal normative aspect.

Firstly, Islam could color traditions or the traditions' ability to soften so that it could become part of itself. In this process, the values of Islam could influence the traditions in the form of religious rituals, arts and norms. In other words, Islam has taken part in coloring rituals of local communities. The results of the negotiation process are possible local Muslim traditions practiced in various areas.

In the form of norms, for example. In Minangkabau there was a struggle in cultural spaces how Islam held a dialogue with local traditions. There is an adage "Adat Basandi Syarak, Syarak Basandi Kitabullah" (customs are based on religion, religion is based on the Qurán) and "Syarak mangato, adat mamakai" (religion designs, customs use). This adage clearly states that any customs should stand and be based on the primary sources, namely the Qur'an and Hadith. That means everything that is contrary to the teachings of Islam must be removed from the lives of indigenous or local cultures of Minangkabau. At this point, there is a monopoly of religious interpretation of the Minangkabau's traditional life. Even, not just a monopoly, but it is also an effort to simultaneously dominate all meanings and understandings of cultures themselves. ${ }^{32}$

This adage was supposedly the result of post-Paderi war reconciliation in the 19th century. The Padri war was a fight between the Indigenous people and the Puritan Muslims. The rigid teachings of

${ }^{32}$ Edy Utama, “Adat Basandi Syarak, Syarak Basandi Kitabullah”, in Ahmad Baso, Plesetan Lokalitas: Politik

Pribumisasi Islam (Jakarta: Desantara, 2002), p. 124-5. 
Wahabi propagated by such Muslim scholars as Haji Miskin, Haji Sumaniak and Haji Piobang did make the Indigenous people upset. Especially when Haji Miskin burned the Custom House of the Sikek community. At the time of reconciliation, they agreed to hold negotiations (Islam does not have to replace all the customs, and custom does not have to reject all the teachings of Islam). The result was an agreement to divide the area of truth in the adage "Syarak mamato, custom mamakai". The negotiation process is a natural mechanism that occurs when Islam hold dialogues with the local tradition.

Since the beginning of the 19th century until now, apparently both the customs and Islam managed to accept each other. The tolerance in Islam as shown by the Muslim scholars who do not bring up the matters of high inheritance and marriage seems to have strengthened the relationship between the two value systems.

For example in the form of rituals. There have been many rituals littered fully with with the teachings of Islam. Tahlilan is one of the examples of Islam could bargain the local tradition by performing rituals of society when facing death. If formerly people were busy with religious ceremonies related to the death, then after negotiating with Islam, such ceremonies were filled with Tahlilan.

What is say here is that when Islam was influenced by the traditions of the community, then there is the process of receiving the local traditions or in other words the ability to subdue the influence of traditions that is considered "different" to become part of the traditions. This process usually occured in the architecture of houses of worship and some elements in it. For instance the influence of Islamic Sundanese nuance could be seen on the building of mosques. In Sunda initially there were no many mosques following the architectural style of the Middle East, such as in the form of dome, the entrance and mihrab, but many mosques were taking the local architectural styles.

In the context of the normative negotiation, then the values of negotiation were actually used pragmatically. For example, they were Muslims but they still practiced their traditional rituals. In this case, there was not a process of fusion. Indigenous peoples who are Muslims in Kampung Naga and Citorek example showed that religion and tradition 
were pragmatically treated by the adherents of indigenous people instead of being treated ideologically. For indigenous people who are Muslims there are a collaborative process of two elements, namely religion and traditions which they termed as "paddling between two boats". One hand they believed in the Islamic faith, on the other hand they used ordinances rooted in traditions. How to farm is one of the activities that refers to a tradition that is based on the stars calculation which refers to gods or spirits. It has still been used for the Islamic teachings do not provide rules and instructions on how to farm, moreover ways of planting based on traditions are pragmatically proven to produce better crops. ${ }^{33}$

\section{Indigenization of Islam in the Islam Nusantara Landscape}

The dialectics of Islam with the reality of life is actually the one that constantly accompanies this religion throughout its history. Since the beginning of its birth, Islam has grown and developed in cultural conditions. The reality -admitted or not-has a significant role in bringing Islam to its actual development, so as to arrive at a civilization that represents and is recognized by the world community.

The actualization of Islam in the trajectory of history shows that Islam is inseparable from the aspects of locality, such as Arabic, Persian, Turkish, Indian to Malay. Each is with its own characteristics, but also reflects the values of monotheism as a unity as the common thread that binds firmly to one another.

The idea of Islam Nusantara is genealogically inspired by the indigenization of Islam that once stated by Abdurrahman Wahid (Gus Dur) in the latter half of the 80s. In the "indigenization of Islam", it could be seen how Islam as a normative doctrine comes from God could be accommodated into the cultural spaces without losing their identity. For Gus Dur, the Arabization and processes to identify ourselves with Middle Eastern cultures are a proof that we have been deprived of our own cultural roots. Furthermore, The Arabization is necessarily not in line with the needs. The indigenization is not as an attempt to avoid the emergence of resistance from the forces of local cultures, but instead the

\footnotetext{
${ }^{33}$ Muhammad Harfin Zuhdi, "Dakwah dan Dialektika Akulturasi Budaya”, in Religia, Jurnal Ilmu-Ilmu Keislaman, Vol. 15, No. 1, April, 2012.
} 
culture is not lost. Therefore, the core of indigenization of Islam is not to do a polarization between religion and culture, because it thus is not inevitable. ${ }^{34}$

The indigenization of Islam has actually taken the spirit taught by Walisongo in their dakwa (propagation) to the archipelago around the 15 th century and the 16th in Java. In this context, Walisongo could successfully incorporate the local values in the teachings of Islam that are typical Indonesian. This creativity spawned a new cluster for the reason of Indonesian Islam that not literally and textually imitates Islam in Arab countries. There is no reason of Arabization inherent in the spread of Islam in the archipelago. It is of course different from that in the next period, namely the 17th century through such prominent ulema as Abdurrauf Sinkili and Muhammad Yusuf al-Makassari that based their lines of thought more on the purification in the renewal of Islam.

Walisongo could precisely accommodate Islam as a religious teaching through the process of history along with local cultures. For example, what is done by Sunan Bonang by changing the Javanese gamelan that was in the time condensed with Hindu aesthetics by encouraging a love of transcendental life. The song "Tombo Ati" is one of his works. Even, in the puppet show, Sunan Bonang changed its characters and inserted Islam nuanced interpretations in it.

Therefore, the "Indigenous Islam" as the answer of the authentic Islam presupposes three things. Firstly, 'Indegenous Islam' has contextual characters in the sense that Islam is understood as a doctrine in the context of time and place. The time change and regional differences are the key to interpret the teachings. Thus, Islam will undergo changes and dynamics in response to changing times. Secondly, 'Indigenous Islam' is progressive, ie the advancement of age should not be understood as a threat to possible deviations from the basic teachings of the religion (Islam), but is seen as a trigger to perform an intense creative response. Thirdly, 'Indigenous Islam' has a liberating character. On this point, Islam is the doctrine that can address human problems universally regardless of differences in religion and ethnicity. Thus,

\footnotetext{
${ }^{34}$ Abdurrahman Wahid, Pergulatan Negara, Agama, dan Kebudayaan (Jakarta: Desantara, 2001), p. 111.
} 


\section{Promoting Islam Nusantara}

Islam is not stiff and rigid in the face of social reality that is always changing.

In this context, 'Indigenous Islam' aims to deal with puritanism, authentication, and any form of purification of Islam while also maintaining local wisdom without losing the normative identity of Islam. Because of that, 'Indigenous Islam' focuses more on cultural ideology which takes into account the differences of locality rather than centralized cultural ideology, which recognizes only religious teachings without interpretation. So it can be spread in many regions without damaging the local cultures. Thus, there will be no practices of radicalism that are supported by extreme religious teachings being capable of posing a threat to peace. ${ }^{35}$

Furthermore, in taking into account the socio-historical conditions in regard with the text of the Qur'an revealed to Prophet Muhammad, it could be concluded that there was a dialectical relationship between the text of the Quran and cultural reality. On this stand, the religious traditions could be changed in accordance with the social and cultural context of a society. Islam is a movement that is open and gives hope to all social groups, regardless of religion, class, ethnicity and gender in reinforcing their self-identification to the locality critically. ${ }^{36}$

In its action, the indigenous Islam has always considered the importance of addressing the needs of local communities, in formulating the religious laws without changing the fundamental principle of Islam. While the core tenets of Islam are aimed at providing constructive control of the locality irregularities. In terms of local traditions that are deviant, hegemonic, unjust, then the indigenous Islam will voice its criticism. While the the local traditions that guarantee justice, and prosperity in their communities, the indigenous Islam will greatly appreciate the traditions. In fact, the great local traditions in the

\footnotetext{
${ }^{35}$ Khamami Zada, "Islam Pribumi: Mencari Wajah Islam Indonesia”, in Tashwirul Afkar, jurnal Refleksi Pemikiran Keagamaan \& Kebudayaan, Edisi No. 14, 2003.

${ }^{36}$ Jadul Maula, "Syariat [Kebudayaan] Islam: Lokalitas dan Universalitas", in Islam Transformatif dan Toleran (Yogyakarta: LkiS), 2002
} 
indigenous Islam's view could probably determine the truthfulness of the text of the Qurán and Hadits.

On this stand, it is understandable that there have been many experts in the principles of Islamic jurisprudense (usul fiqh) saying that knowing the Arab social and historical setting related to the formation of religious requirements as reflected in sacred texts is extremely vital and significant. Al-Syathibi in the al-Muwaffaqat fi Usul al-Shari'ah, stated that knowing the social conditions of Arab society, as the locus of early revelation of the Qur'an and the situation when a text of the Qur'an revealed is one of the requirements that must be taken into account by a mufassir. On this point al-Syathibi called for the importance of knowing the significance of a text not only from the grammatical aspect but also from the socio-cultural one as that in the era of the revelation of the Qur'an.

Ahmad Baso in his book, Islam Nusantara Ijtihad Genius and Ijma 'Ulama Indonesia, analogies that Islam Nusantara is like the meeting of two saplings of different types, but when put together in the process of crossing the two will generate a new superior seed variety. The combination of Islam and Nusantara is required to obtain a new genius with expected new seeds of characters. These seeds will grow up healthy and can survive in any situation and and will be tolerant and adaptive to any environment. By combining the two different species it is expected that new populist species will appear, especially in dealing with various conditions and challenges. And the new species is called Islam Nusantara. ${ }^{37}$

Furthermore, Greg Barton has also reflected the ideas of $\mathrm{KH}$ Abdurrahman Wahid (Gus Dur) in viewing Islam. According to Gus Dur, Islam is not static and not in need of both reformulation and reapplication. In other words, he argues that the essential characteristic of Islamic law is its necessity to be interpreted contextually. Because if

\footnotetext{
${ }^{37}$ Ahmad Baso, Islam Nusantara Ijtihad Jenius dan Ijma’ Ulama Indonesia, (Jakarta: Pustaka Afid, 2015), p. 17-18.
} 
the social and historical context changes, then the application of the eternal principles of Islam also changes. ${ }^{38}$

While Azyumardi Azra assumes that Islam Nusantara especially represented by NU and other tolerant mass organizations have almost all the potential to creat a civilization that becomes a blessing for the universe (rahmatan lil alamin). The organization's capital is the emergence of various institutions such as mosques, Islamic boarding schools (pesantren), madrasas, universities, hospitals and clinics, homes for social services, cooperatives, and other economic activities.

Consequently, there have been many world's Muslim scholars since the late 1980s, such as Fazlur Rahman looking at the potential of Islam Nusantara to stand in the forefront in advancing the global Islamic civilization. With the NU concept reflected in the Islam Nusantara, the Indonesia's largest Muslim organization could contribute to create world civilization both peacefully and harmoniously. Such expectations, according Azyumardi Azra, have increased amid continuing conflict in the Muslim countries of the Arab world, South Asia, West Asia and Africa. To that end, not only should the NU and other Islamic organizations do their best for the country, but should also take part in internationalizing their moderate and tolerant teachings of Islam to other countries. Thus, Islam Nusantara is able to stand at the forefront in realizing Islam as a blessing for the universe (rahmatan lil alamin) ${ }^{39}$

\section{E. Conclusion}

Islam Nusantara having so far been propagated by Nahdlatul Ulama is not a movement to change the doctrine of Islam for it came to the country as a guest and was later adopted in cultural spaces. Consequently, Islam Nusantara developed a distict character that is very differenct from that manifested by Islam in other Muslim countries, especially the Middle East.

The Muslim countries in the Middle East, for example, have commonly considered Islam as a socioreligious and even political system

\footnotetext{
${ }^{38}$ Greg Fealy (eds.), Tradisionalisme Radikal: Persinggungan Nahdlatul UlamaNegara, trans. Ahmad Suaedy (Yogyakarta: LKiS, 1997), p. 176.

${ }^{39}$ Azyumardi Azra, "Islam Indonesia Berkelanjutan", in Opini Kompas, 3 August 2015."
} 
that is absolutely "complete," "final" and authoritative, offering human beings no choice but to comply with the dictates of that final construction. In Nusantara, on the other hand, Islam is in a state of constant learning. For hundreds of years, its leading practitioners have carefully studied social reality, in order to ascertain the most elegant means to achieve their goals in addition to maintaining harmony within a diverse and pluralistic society.

Although the model of Islam Nusantara is different from that in the Middle East, this does not mean that it constitutes any form of heresy. Prominent ulema (religious scholars) and other Muslim leaders in Nusantara could ensure that the ulema in practicing and promoting Islam adhered to the fundamental Islamic teachings in addition to following its intellectual traditions and maintaining an inseverable bond to the established references of classical Islam.

Even NU with its Islam Nusantara agenda could profoundly sow the seeds of its teachings in maintaining and enriching the civilization of Nusantara as if Islam found itself in "paradise". The Indonesia's largest Muslim organization could play an important role in addition to enjoying the widest possible opportunity to engage in negotiations with social and historical reality.

Within this nonpoliticized atmosphere, Islam Nusantara has been widely voiced by the Nahdlatul Ulama by grounding its core teachings in public life to many parts of the world. All this is due to the fact that the NU Islam Nusantara agenda is not but to empathize with others and engage in any constructive dialogue with reality. Moreover, the NU realizes that the success of Islam Nusantara stems from its conviction that religion should serve as a path to enlightenment for human beings and that Islamic law should serve to promote the prosperity of humanity, rather than function as a means of repressive authority. It is simultaneously a reminder and an offer to the world - an invitation to imbue social, cultural, political and religious life with love and spiritual beauty.

Islam Nusantara nationally and internationally propagated by NU is a typical Indonesian Islam that promotes tolerance in addition to accepting differences, whether religious, ethnic, racial, or cultural. Thus, 
the NU doctrine of Islam Nusantara becomes a stepping stone in building solidarity through such inclusive values as tawasuth (moderation), tasamuh (tolerance), taáwun (mutual help), tawazun (harmony), and others.

Last but not least, on account of the NU contribution to the nation in materalizing the moderate teachings of Islam, it s a good time for the world, especially the Muslim countries to consider the importance of practicing the values of Islam Nusantara as explicitly voiced by the Indonesia's largest Muslim organization. Of course, the Muslim countries should pay more attention to their own socio-cultural conditions and local wisdom. 


\section{Bibliography}

Abdullah, Taufik, "Pengantar: Islam, Sejarah dan Masyarakat", in Taufik Abdullah [ed.], Sejarah dan Masyarakat: Lintasan Historis Islam di Indonesia. Jakarta: Pustaka Firdaus, 1987

Ali, Fachry, Agama, Islam dan Pembangunan. Yogyakarta: PLP2M, 1985

Algadari, Hamid, Dutch Policy Against Islam and Indonesian of Arab Descent in Indonesia. Jakarta: LP3ES, 1994

Ambary, Hasan Muarif, Menemukan Peradaban; Jejak Arkeologis dan Historis Islam Indonesia. Jakarta: Logos Wacana Ilmu, 2001

Azra, Azyumardi dan Hudson, Wayne (eds.), Islam beyond Conflict: Indonesian Islam and Western Political Theory. England:

Ashgate Publishing Limited, 2008

Azra, Azyumardi, "Islam Indonesia Berkelanjutan", in Opini Kompas, 3 Agustus 2015.

Arbiyah, Lubis, Pemikiran Muhammadiyah dan Muhammad Abduh: Suatu studi Perbandingan Jakarta: Bulan Bintang, 1993

Baso, Ahmad, Plesetan Lokalitas: Politik Pribumisasi Islam. Jakarta: Desantara, 2002 Islam Nusantara Ijtihad Jenius dan Ijma' Ulama Indonesia. Jakarta: Pustaka Afid, 2015

Bresnan, John, Indonesia: The Great Tradition. Maryland, Roman and Littlefield Publishers, Inc., 2005

Braswell, George W., Islam: Its Prophet, Peoples, Politics and Power. Nashville: Broadman \& Holman Publishers, 1996

Cornell, Vincent J. (ed.), Voices of Islam, Vol. 5. London: Praeger Publisher, 2007

Fealy, Greg (eds.), Tradisionalisme Radikal: Persinggungan Nahdlatul Ulama Negara, terj. Ahmad Suaedy. Yogyakarta: LKiS, 1997

Fasya, Teuku Kemal, "Dimensi Puitis dan Kultural Islam Nusantara", in Opini Kompas, 4 August 2015 
Geertz, Hildred, "Indonesian Cultures and Communities," in Indonesia, Ruth T. McVey (ed.). New Haven, CT: Human Relations Area Files, 1963

Geerrtz, Clifford, The Interpretation of Cultures. New York: Basic Books, 1973

Hanson, F. Allan, Meaning in Culture. London and New York: Routledge, 2004

Iyubenu, Edi AH, "Ontran-Ontran Islam Nusantara", in Opini Jawa Pos, 24 Juli 2015.

Maula, Jadul, "Syariat [Kebudayaan] Islam: Lokalitas dan Universalitas", makalah Islam Transformatif dan Toleran. Yogyakarta: LkiS, 2002.

Munandar, Agus Aris, "Kegiatan Keagamaan di Pawitra Gunung Suci di Jawa Timur Abad 14-15", Tesis, Magister Humaniora Fakultas Sastra Universitas Indonesia, 1990

Parkin, Harry, Batak Fruit of Hindu Thought. India: Christian Literature Society, 1978

Poespowardojo, Soerjanto, "Pengertian Local Genius dan Relevansinya dalam Modernisasi" dalam Kepribadian Budaya Bangsa (local genius), Ayotrohaedi (ed.). Jakarta: Pustaka Jaya, 1986

Prayitno, Arohman dan Rahardiansyah P., Trubus, Ethics for a Multicultural Society: Strategic Solutions for Interweaving Togetherness the Frame Work of Pluralism. Jakarta: Trisakti University Press, 2008

Renard, John, Tales of God's Friends: Islamic Hagiography in Translation. California: University of California Press, 2009

Sahal, Akhmad (eds.), Islam Nusantara Dari Ushul Figh hingga Paham Kebangsaan, Cet. I. Bandung: Mizan Pustaka, 2015

Siroj, Said Aqil, Islam Sumber Inspirasi Budaya Nusantara Menuju Masyarakat Mutamaddin. Jakarta Pusat: LTN NU, 2015 
Sunyoto, Agus, Walisongo: Rekonstruksi Sejarah yang Disingkirkan. Jakarta: Transpustaka, 2011

Tibbi, Bassas, Islam and Cultutral Accommodation of Social Change. San Francisco: Westview Press, 1991

Utama, Edy, “Adat Basandi Syarak, Syarak Basandi Kitabullah", in Ahmad Baso, Plesetan Lokalitas: Politik Pribumisasi Islam. Jakarta: Desantara, 2002

Wahid, Abdurrahman, Pergulatan Negara, Agama, dan Kebudayaan. Jakarta: Desantara, 2001

--------- Islam Kosmopolitan: Nilai-Nilai Indonesia dan Transformasi Kebudayaan (Jakarta: The Wahid Institute, 2007

Walsh, Mary-Paula, Feminism and Christian Tradition: An Annotated Bibliography and Critical Introduction to the Literature. London, Greenwood Press, 1999

Zada, Khamami, "Islam Pribumi: Mencari Wajah Islam Indonesia", dalam Tashwirul Afkar, jurnal Refleksi Pemikiran Keagamaan \& Kebudayaan, No. 14, 2003

Zuhdi, Muhammad Harfin, Parokialitas Adat terhadap Pola Keberagamaan Komunitas Islam Wetu Telu di Bayan Lombok. Jakarta: Lemlit UIN Jakarta, 2009 